\title{
Acute Hepatitis as a Rare Presentation of COVID-19
}

\author{
Abat Khan ${ }^{1}$, Ihtisham Qayum ${ }^{2}$, Abdul Wali Khan ${ }^{3}$, Muhammad Hanif ${ }^{1}$ and Awais Naeem ${ }^{2}$ \\ ${ }^{1}$ Department of Cardiology, Khyber Teaching Hospital, Peshawar, Pakistan \\ ${ }^{2}$ Department of Internal Medicine, Khyber Teaching Hospital, Peshawar, Pakistan \\ ${ }^{3}$ Department of Internal Medicine, Hayatabad Medical Complex, Peshawar, Pakistan
}

\begin{abstract}
Coronavirus disease 2019 (COVID-19) initially emerged in Wuhan, China, in December 2019, and now it has been declared a pandemic by the World Health Organization. COVID-19 commonly presents with respiratory manifestations like fever, cough, body aches, and shortness of breath. Neurological, myocardial, renal and gastrointestinal complications secondary to SARS-CoV-2 infection have been reported in the literature. Gastrointestinal symptoms reported with COVID-19 are mostly nausea, vomiting, and diarrhea. COVID-19 can rarely present with acute hepatitis. Here, we report a case of a 45-year male who presented with signs and symptoms of acute hepatitis secondary to SARS-CoV-2 infection.
\end{abstract}

Key Words: SARS-CoV-2, COVID-19, Acute hepatitis.

How to cite this article: Khan A, Qayum I, Khan AW, Hanif M, Naeem A. Acute Hepatitis as a Rare Presentation of COVID-19. J Coll Physicians Surg Pak 2021; 31(JCPSPCR):CR125-CR126.

\section{INTRODUCTION}

Coronavirus disease 2019 (COVID-19) initially began as clusters of atypical pneumonia in Wuhan, China, in December 2019, and now it has caused approximately one million deaths around the globe. SARS-CoV-2 infection is mostly asymptomatic and commonly presents with respiratory symptoms like fever, shortness of breath, and cough. ${ }^{1}$ In the literature, COVID-19 has been reported with various renal, myocardial, neurological, and gastrointestinal complications., ${ }^{2,3}$ Similarly, hepatobiliary complications, i.e. abnormal liver function tests and rarely acute hepatitis, have been reported with SARS-CoV-2 infection. ${ }^{4}$ Wander et al. reported the first case of acute non-icteric hepatitis caused by SARS-CoV-2, who presented to the emergency department with dark urine and was later diagnosed as a case of acute hepatitis secondary to SARS-CoV- $2 .{ }^{5}$ Here, we report a case of a 45-year male patient who initially presented with signs and symptoms of acute hepatitis and was later on diagnosed with acute hepatitis secondary to SARS-CoV-2 infection.

\section{CASE REPORT}

A 45-year male with an insignificant past medical history presented to the Emergency Department with five days' history of nausea, vomiting, and fever.

Correspondence to: Dr. Muhammad Hanif, Department of Internal Medicine, Hayatabad Medical Complex,

Peshawar, Pakistan

E-mail: hanifafridi273@gmail.com

Received: September 29, 2020; Revised: February 22, 2021; Accepted: April 18, 2021

DOI: https://doi.org/10.29271/jcpsp.2021.JCPSPCR.CR125
On examination, his blood pressure was $115 / 75 \mathrm{mmHg}$, pulse $110 /$ min, oxygen saturation $96 \%$, and temperature was $101^{\circ} \mathrm{F}$. Abdominal examination was unremarkable except for tender right hypochondrium. Baseline investigations showed a high level of alanine aminotransaminase (ALT) $1750 \mathrm{U} / \mathrm{L}$, aspartate aminotransaminase (AST) $1801 \mathrm{U} / \mathrm{L}$, total bilirubin of $2 \mathrm{mg} / \mathrm{dl}$, and an alkaline phosphatase of $204 \mathrm{U} / \mathrm{L}$. He was admitted as a case of acute hepatitis in the isolation unit and started on intravenous dextrose saline $1000 \mathrm{ml}$ twice a day, injectable dimenhydrinate as needed, and omeprazole $40 \mathrm{mg}$ once a day. As per the hospital's protocol, inflammatory markers and a nasopharyngeal swab test for COVID-19 on quantitative reverse-transcriptase-polymerase-chain reaction ( $\mathrm{RRT}$-PCR) assay were sent. The inflammatory markers were raised (Table I), and he developed a dry cough on the second day of admission.

Chest X-ray showed mild bilateral infiltrates. He was started on injectable azithromycin $10 \mathrm{mg} / \mathrm{kg} /$ day, ceftriaxone 50 $\mathrm{mg} / \mathrm{kg} /$ day, and enoxaparin $40 \mathrm{mg}$ subcutaneous once a day. Serological tests for hepatitis A, B, C, and E viruses, Epstein-Barr virus, cytomegalovirus virus, blood cultures, and autoimmune markers were negative (Tablell).

The qRT-PCR result was positive for SARS-CoV-2 infection. The patient had no history of alcohol intake and hepatotoxic drug use. He was diagnosed with acute hepatitis secondary to SARS-CoV-2, because no other causative factor was found despite thorough work-up. On fifth day of admission, his condition improved, and he was discharged and was advised to follow-up as an outpatient.

\section{DISCUSSION}

SARS-CoV-2 causing COVID-19 mostly presents as fever, cough, shortness of breath, fatigue, and headache. Acute hepatitis associated with SARS-COV-2 has been rarely reported. For instance, the first biopsy-proven acute hepatitis secondary to SARS-CoV-2 
in a female infant who was a liver allograft recipient and whose donor subsequently tested positive for COVID-19 was reported by Lagana etal. ${ }^{6}$

Table I: Laboratory findings.

\begin{tabular}{|l|l|}
\hline Test & Result \\
\hline Hemoglobin & $11.4 \mathrm{~g} / \mathrm{dl}$ \\
\hline Total lymphocyte count & $13.8 \times 10^{9} / \mathrm{l}$ \\
\hline Red blood cells & $4.3 \times 10^{12} / \mathrm{l}$ \\
\hline Platelets & $390 \times 10^{9} / \mathrm{l}$ \\
\hline Prothrombin time & $\begin{array}{l}13 \mathrm{~seconds} \\
(12 \mathrm{~seconds} \text { control) }\end{array}$ \\
\hline Activated partial thromboplastin time & $\begin{array}{l}33 \mathrm{~seconds} \\
(28 \mathrm{~seconds} \text { control) }\end{array}$ \\
\hline & $\begin{array}{l}874 \mathrm{ng} / \mathrm{FEUml} \\
(\text { reference value: } \\
\text { upto } 500 \mathrm{ng} / \mathrm{FEUml})\end{array}$ \\
\hline D-dimers & $17.2 \mathrm{mg} / \mathrm{dl}$ \\
\hline C-Reactive protein & $725 \mathrm{U} / \mathrm{l}$ \\
\hline Lactate dehydrogenase (LDH) & $1178.6 \mathrm{\mu g} / \mathrm{l}$ \\
\hline Serum Ferritin & $1750 \mathrm{U} / \mathrm{l}$ \\
\hline Alanine aminotransaminase (ALT) & $1801 \mathrm{U} / \mathrm{l}$ \\
\hline Aspartate aminotransaminase (AST) & $204 \mathrm{U} / \mathrm{l}$ \\
\hline Alkaline phosphatase & $2 \mathrm{mg} / \mathrm{dl}$ \\
\hline Total bilirubin & $51 \mathrm{mg} / \mathrm{dL}$ \\
\hline Blood urea & $0.6 \mathrm{mg} / \mathrm{dl}$ \\
\hline Creatinine & $137.2 \mathrm{mEq} / \mathrm{l}$ \\
\hline Sodium & $3.92 \mathrm{mEq} / \mathrm{l}$ \\
\hline Potassium &
\end{tabular}

Table Il: Additional laboratory findings.

\begin{tabular}{|l|l|}
\hline Investigations & Results \\
\hline Anti-hepatitis A antibody (IgM/lgG) & Negative/Negative \\
\hline HBs antigen & Negative \\
\hline Anti-HBs antibody & Negative \\
\hline Anti-HBC antibody & Negative \\
\hline Anti-HCV antibody & Negative \\
\hline Anti-Hepatitis E antibody (IgM/lgG) & Negative/Negative \\
\hline Anti-CMV antibody ( IgM/lgG) & Negative/ Negative \\
\hline Anti-EBV antibody (IgM/lgG) & Negative/ Negative \\
\hline Blood Culture & Negative for any pathogens \\
\hline ANA Screening & Negative \\
\hline
\end{tabular}

Chen et al. conducted a study to evaluate clinical manifestations in 99 COVID-19 patients and found that $35 \%$ of patients had a mild elevation of AST (mean $34 \mathrm{U} / \mathrm{L}$ ) and $28 \%$ a mild elevation of ALT (mean $39 \mathrm{U} / \mathrm{L}$ ), but only one $(0.9 \%)$ out of 99 patients had a high level of ALT and AST (ALT, $7590 \mathrm{U} / \mathrm{L}, \mathrm{AST}, 1445 \mathrm{U} / \mathrm{L}$ ). ${ }^{7}$ Several mechanisms have been proposed to explain how SARS-COV-2 causes liver injury. The possible mechanisms include: Immune-mediated injuries: Inflammatory biomarkers could be the cause of liver injuries in COVID-19 patients as they are significantly elevated in COVID-19 patients. ${ }^{8}$ Hypoxic and Anoxic injuries: Respiratory failure is the hallmark of COVID-19, and hypoxia and anoxia could bethe possiblecause of hepatic injuries. ${ }^{8}$ Direct cytotoxicity: Angiotensin-converting enzyme 2 (ACE2) receptors the potential targets of SARS-CoV-2 viral entry. ACE2 receptors are abundant in the liver and could be the cause of liver injuries. ${ }^{9}$ Mild hepatic damage is common in SARS-CoV-2 due to the above possible mechanisms, but severe acute hepatitis is a rare occurrence. In our case, the patient presented with signs and symptoms of acute hepatitis and was later diagnosed as COVID-19.
Acute hepatitis is an atypical and rare presentation of COVID-19, which occurred before developing typical respiratory symptoms of cough, shortness of breath in this case. During this pandemic, physicians should keep in mind such rare manifestations and presentations of SARS-COV-2 infections to decrease the spread and mortality of COVID-19.

\section{PATIENT'S CONSENT:}

Written informed consent was taken from the patient.

\section{CONFLICT OF INTEREST:}

The authors declared no conflict of interest.

\section{AUTHORS' CONTRIBUTION:}

AK: Collected the data.

AK, IQ, AWK, MH and AN: Wrote the initial manuscript.

MH and AWK: Critically revised the manuscript.

All authors have read the final manuscript.

\section{REFERENCES}

1. Wang D, Hu B, Hu C, Zhu F, Liu X, Zhang J, et al. Clinical characteristics of 138 hospitalised patients with 2019 novel coronavirus-infected pneumonia in Wuhan, China. JAMA 2020; 323(11):1061-9. doi:10.1001/jama.2020.1585.

2. Ahmed MU, Hanif M, Ali MJ, Haider MA, Kherani D, Memon GM, et al. Neurological manifestations of COVID-19 (SARSCoV-2): A review. Front Neurol 2020; 11:518. doi:10.3389/ fneur.2020.00518.

3. Tian Y, Rong L, Nian W, He Y. Review article: Gastrointestinal features in COVID-19 and the possibility of faecal transmission. Aliment Pharmacol Ther 2020; 51(9):843-51. doi:10.1111/apt.15731.

4. Patel KP, Patel PA, Vunnam RR, Hewlett AT, Jain R, Jing R, et al. Gastrointestinal, hepatobiliary, and pancreatic manifestations of COVID-19. J Clin Virol 2020; 128:104386. doi:10.1016/j.jcv.2020.104386.

5. Wander P, Epstein M, Bernstein D. COVID-19 Presenting as Acute Hepatitis. Am J Gastroenterol 2020; 115(6):941-2. doi:10.14309/ajg.0000000000000660.

6. Lagana SM, De Michele S, Lee MJ, Emond JC, Griesemer AD, Tulin-Silver SA, et al. COVID-19-associated hepatitis complicating recent living donor liver transplantation. Arch Pathol Lab Med 2020; 10.5858/arpa.2020-0186-SA. doi:10.5858/arpa.2020-0186-SA.

7. Chen N, Zhou M, Dong X, Qu J, Gong F, Han Y, et al. Epidemiological and clinical characteristics of 99 cases of 2019 novel coronavirus pneumonia in Wuhan, China: A descriptive study. Lancet 2020; 395(10223):507-13. doi:10.1016/S0140-6736(20)30211-7.

8. Sun J, Aghemo A, Forner A, Valenti L. COVID-19 and liver disease. Liver Int 2020; 40(6):1278-81. doi:10.1111/ liv. 14470.

9. Chai X, Hu L, Zhang Y, Han W, Lu Z, Ke A, et al. Specific ACE2 expression in cholangiocytes may cause liver damage after 2019-nCoV infection. bioRxiv 2020. doi.org/10.1101/ 2020.02.03.93176. 